\title{
ECONOMIC-POLITICAL DEVELOPMENT AND ENVIRONMENTAL CHANGES IN FORMER CZECHOSLOVAKIA 1948-1989
}

\begin{abstract}
L. J el e č e k : Economic-Political Development and Environmental Changes in Former Czechoslovakia 1948-1989. - Sborník CGS, 99, 2, pn. 79 - 92 (1994). - This paper outlines the recent state of environinent in former Czechoslovakia on the background of some historico-geographical features. Special attention is devoted to the period 1948-1989. Main trends in unfavorable environmental changes, their political, social, and economic causes, connections and consequences are discussed. Some possible solution of the recent environmental situation are indicated.
\end{abstract}

KEY WORDS: Czechoslovakia - environmental changes - period 1948-1989.

\section{Introduction}

One of the most polluted area in Europe covers north-western part of the Czech Republic, former East Germany, and southern Poland - see figure No. 1. Former Czechoslovakia was the largest producer of nitrogen oxides in relation to GNP in the world. As regards sulphur dioxide, in 1988 it occupied second place after East Germany (State of the World, p. 96). Measured by total amount of sulphur dioxide emissions, Czechoslovakia occupied the 6th place. Out of Western European countries, only Great Britain and Spain - with much larger economic bases - were "more ahead" (State of the Environment...). Deep concern with environmental issues was among motivations which led to substantial changes of the social-political system in Central Europe - and to the breakup of Communism in the former Soviet Block.

In this article, which is based on previously published papers (Jeleček 1988, 1993), I will attempt to describe the recent state of environment in Czechoslovakia, especially in the Czech Republic, and to indicate some causes of its unfavorable development.

Table 1

Main geographical features of Czechoslovakia (1989)

\begin{tabular}{|lrccccc|}
\hline Country & $\begin{array}{c}\text { Area } \\
\mathrm{km}^{2}\end{array}$ & $\begin{array}{c}\text { Popul. } \\
\text { (mil.) }\end{array}$ & $\begin{array}{c}\text { Popul. } \\
\text { density } \\
\text { (inhab./km }\end{array}$ & AL & $\begin{array}{c}\text { \% of total territ. } \\
\text { ARL }\end{array}$ & F \\
\hline Czechoslovakia & 127,900 & 15.6 & 122 & 52.7 & 37.1 & 36.1 \\
Czech Republic & 78,864 & 10.4 & 132 & 54.5 & 41.0 & 33.3 \\
Slovak Republic & 49,036 & 5.3 & 108 & 50.0 & 30.8 & 40.5 \\
\hline
\end{tabular}

Source: Statistická ročenka ČSFR 1992

Abbrevations: $\mathrm{AL}=$ agricultural land; $\mathrm{ARL}=$ arable land; $\mathrm{F}=$ forests

On January 1, 1993, Czechoslovakia - after almost 75 years of existence - was divided to two independent states: Czech Republic (often abbreviated as "CR", or referred to as 
"Czech Lands", especially in historical context) and Slovak Republic ("SR", or "Slovakia"). I will examine the territory of Czechoslovakia on whole: this state existed until 1992 as one political entity and its territory still creates a specific unit due to common history of both parts. A short historical introduction is essential; without knowledge of this history, contemporary situation can not be thoroughly explained and it would be more difficult to forecast future trends.

\section{Some Historico-Geographical Features of the Development of Czechoslovakia}

Since the beginning of Industrial Revolution in the first half of the 19th century substantial changes of landscape and environment have been caused by the processes of industrialization, urbanization and - as regards agricultural regions - also by agricultural revolution. New territorial distribution of industry, population, and transport connections emerged during the second half of the 19th century, together with creation of basic features of industrial regions and productional agricultural regions. Czech Lands ranked among the most industrialized part of the Hapsburg Monarchy.

These basic features were partly changed due to the new geopolitical and geoeconomic position of Czechoslovakia between 1918 and 1938, especially in relation to the breakup of the Hapsburg Monarchy and its large and custom-free markets. The role of heavy industry was much emphasized and industrialization of Slovakia began. Largescale extraction of black coal (with major deposits being in northern Moravia) and especially of brown coal of relatively poor quality typified that period. This coal has low fuel efficiency (about $12.5 \mathrm{MJ}$ per $\mathrm{kg}$ ) and quite a high content of sulphure (on average 1.5 to $2.35 \%$, but in some localities as much as $8-11 \%$ of sulphur). Rich deposits of this coal are found mostly in north-western Bohemia, at the foot of the Ore Mountains (Krušné hory).

In the beginning of the period of industrialization most of industry was concentrated in northern Bohemia, close to mountain ranges containing rich sources of water energy and timber. From the environmental point of view it is important that new power plants were located (and old plants reconstructed and extended) in early industrial regions together with the heavy industry. Czechoslovak economy began to be much dependent on the coal industry; on the other hand, light industry gradually lost its former importance. Iron and steel metallurgy, heavy engineering and chemical industry became leading branches. This shift towards heavy industry was accelerated in 1920s and 1930s under the threat of Nazi Germany. A lot of new investments (mostly military production) were geared to central Slovakia, which was originally much an agricultural country.

After 1948, the large shift of economic structure towards heavy industry became more pronounced and led to a fast and essential restructuring of the entire economy with deep social, economic and environmental consequences. The economic structure was thoroughly transformed in 1950s and 1960s. High demand of natural resources, raw materials and energy became the most typical features. It was necessary to import many raw materials, mainly from the Soviet Union. The above mentioned character of Czechoslovak economy was also affected by a relatively low degree of technological development (caused, among others, also by the existence of the "Iron Curtain"), and enhanced by the high specific consumption of material and energy per one unit of production and by lower quality of products. These circumstances have contributed significantly to increased environmental deterioration, especially in 1970s. 
Table 2

Development of Czechoslovak economy - basic indicators $1937(1950)-1989$ (1937 or $1950=100)$

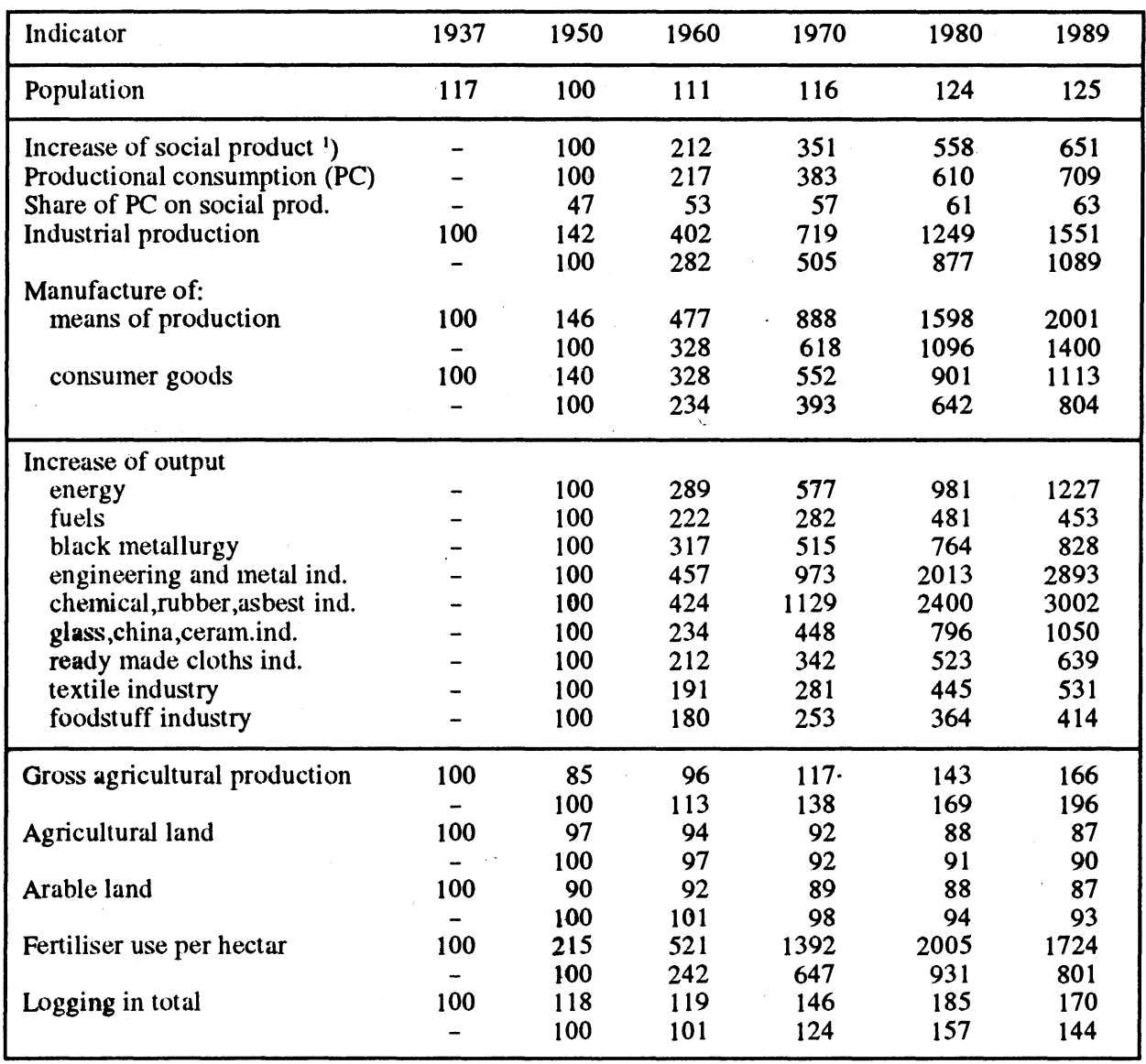

1) social product approximately equals GNP

Source: Statistická ročenka...1991, p. 34-39.

Table No 2 shows, for instance, the high share of productional consumption in social product. Important differences between the rapid growth of output of means of production and the production of consumer goods, between the sharp increase of energy output and metallurgy on the one side and much slower growth of textile, foodstuff, and glass industries on the other side are clerly revealed, too.

\section{Recent State of Environment and Major Trends in between 1948 - 1989}

It is difficult to describe basic trends in environmental changes during the Communist era in Czechoslovakia due to the lack of long-term data. Some information was published in English (see references). It was almost impossible to collect and examine reliable long-term data, since many pollutants were not recorded in a systematic way and in many cases there are no available data at all.

Environmental deterioration in Czechoslovakia has many different faces. The most important features are listed as follows: 
- airborne pollution, acid rains and forest degradation;

- pollution of rivers and groundwater pollution and man-induced changes of the natural water circulation;

- pollution of agricultural land (mainly arable land) and consequent degradation; soil erosion;

- biodiversity threatening and man-induced changes of bio-geochemical circulation;

- irreversible losses of land due to mining, construction and waste disposal;

- (last, but not least) negative impacts on the health of population.

\subsection{Air Pollution}

Air pollution has become the greatest environmental issue, especially in the Czech Republic. Many related problems are derived from this type of pollution. International comparison gives a comprehensive picture. The sulphur dioxide emissions have decreased in the course of 1980s in almost all European countries. In western countries, the average decrease in between 1980-1988 was $50 \%$; in Czechoslovakia, however, only $9.7 \%$. Sulphuric emissions have in the same period increased only in former East Germany and Poland (23.3\% and $2.0 \%$ respectively).

Table 3

Specific emissions of $\mathrm{SO}_{2}$ and $\mathrm{NO}_{\mathrm{x}}$ in selected countries, period 1980-1987 (in tons $/ \mathrm{km}^{2}$ )

\begin{tabular}{|c|c|c|c|c|c|c|}
\hline Country & $1980 \mathrm{SO}_{2}$ & 1987 & $\begin{array}{c}\text { Index } \\
1987 / 1980\end{array}$ & $1980^{\mathrm{NO}_{x}}$ & 1987 & $\begin{array}{l}\text { Index } \\
1987 / 1980\end{array}$ \\
\hline Czechoslovakia & 24.2 & 22.7 & 94 & 9.4 & $8.8^{1}$ & 94 \\
\hline W. Germany & 12.9 & 8.2 & 64 & 12.5 & 11.7 & 94 \\
\hline E. Germany & 46.3 & 46.3 & 100 & - & $8.8^{2}$ & - \\
\hline Poland & 13.1 & 14.5 & 111 & - & $4.8^{3}$ & - \\
\hline Hungary & 17.6 & 15.3 & 87 & - & $3.2^{2}$ & - \\
\hline Austria & 4.2 & 1.8 & 43 & 2.6 & 2.6 & 100 \\
\hline Belgium & 25.8 & 15.7 & 61 & 13.6 & 12.4 & 91 \\
\hline U.K. & 19.1 & 15.0 & 79 & 7.8 & 7.5 & 96 \\
\hline U.S.A. & 2.5 & 2.2 & 88 & 2.2 & $2.1^{1}$ & 95 \\
\hline
\end{tabular}

$1=1983$ data; $2=1986$ data; $3=$ unofficial data

Source: National Report..., p. 86.

Most of air pollution in Czechoslovakia was until the end of 1940s confined to mining and industrial regions. Since 1950s, however, more and more areas became affected. All forms of pollution showed steady increase until mid 1980s. Only relatively recently there has been observed some improvements, as indicated in table No. 4. First, the long-term increase of airborne pollutants was primarilly caused by extraordinarilly high level of $\mathrm{SO}_{2}$ emissions which belong among the most poisonous pollutants. There has been a sharp increase of sulphuric emissions until the end of 1960s. The total amount of $\mathrm{SO}_{2}$ increased in the period 1950-1985 from 900 to 2,783 thousand tons (in 19501970 by 1,550 thousand tons, $1970-1985$ by only ca 330 thousand tons) - see table No 4. In the year 1989 the total amount of $\mathrm{SO}_{2}$ emissions was slightly lower, i. e. 2,563 thous. tons. (National Report..., p.84).

Milder winters, industrial stagnation and governmental environmental schemes contributed to a slow decrease of some of the above mentioned features. This tendency continued after 1989 due to decrease of industrial production approximately by $25 \%$ within the period 1989 - 1992, which resulted in first desirable structural changes of Czechoslovak economy. In between 1989 and 1992 the coal extraction decreased by ca $25 \%$ (only 19.5 mil. tons of black coal and 68 mil. tons of brown coal was mined). 
Table No. 4 shows the recent positive environmental development and much better environmental situation in Slovak Republic.

Table 4

Specific emissions of main pollutants in Czechoslovakia (tons $/ \mathrm{km}^{2}$ ) in period 1985-1989 (1991)

\begin{tabular}{|c|c|c|c|c|c|}
\hline \multicolumn{6}{|c|}{ Pollutant } \\
\hline Year & Dust & $\mathrm{SO}_{2}$ & $\mathrm{NO}_{x}$ & $\mathrm{CO}$ & $C_{x} H_{x}$ \\
\hline \multicolumn{6}{|c|}{ Czechoslovakia } \\
\hline 1985 & 10.7 & 21.8 & 7.8 & 9.7 & 1.5 \\
\hline 1988 & 9.0 & 20.9 & 8.2 & 8.5 & 1.6 \\
\hline 1990 & 7.3 & 19.1 & 7.7 & 10.0 & 2.4 \\
\hline \multicolumn{6}{|c|}{ Czech Republic } \\
\hline 1985 & 12.9 & 27.4 & 10.1 & 11.4 & 1.7 \\
\hline 1987 & 12.1 & 27.4 & 10.4 & 9.4 & 1.8 \\
\hline 1989 & 8.5 & 25.2 & 11.7 & 11.2 & 2.9 \\
\hline 1991 & 7.5 & 22.5 & 9.2 & 14.0 & 2.9 \\
\hline \multicolumn{6}{|c|}{ Slovak Republic } \\
\hline 1985 & 7.3 & 12.7 & 4.0 & 6.9 & 1.2 \\
\hline 1987 & 7.1 & 12.4 & 3.9 & 7.0 & 1.3 \\
\hline 1989 & 6.5 & 11.5 & 4.1 & 11.1 & 1.4 \\
\hline
\end{tabular}

Source: National Report, p. 84; Životní prostředí ..., p. 88 (data for CR in 1991).

Among the most important sources of $\mathrm{SO}_{2}$ emissions are power plants and heating stations, which mostly burn low-quality brown coal and oil, both with high content of sulphur. These sources account for $75-80 \%$ of $\mathrm{SO}_{2}$. Considerable pollution comes from local heating, which affects mostly historical town centers, family housing districts and villages $(7 \%)$. Technological processes $(11 \%)$ and exhaust gases from vehicles (3\%) belong also to important sources of pollution (National Report...).

Some positive environmental trends, which occurred in the second half of 1980s in Czechoslovakia, resulted from lower consumption of coal rather than from desulphurization schemes. Originally there was no desulphurization equipment in Czechoslovak plants, in the time being, some is being introduced. Such equipment is quite costly, accounting for $1 / 3-1 / 2$ of the total price of a power plant, and reduces significantly only sulphuric emissions. In most industrial processes, however, desulphurization of waste gases is insufficient. Output of sulphuric emissions reaches in industrial regions and in some cities and towns extremely high levels. In the year 1990 this was 109.8 tons/ $\mathrm{km}^{2}$ in the North Bohemian Region, 16.9 in North Moravian Region, 84.8 tons $/ \mathrm{km}^{2}$ in Prague and 17.8 in Central Bohemian Region. In South Bohemia region the pollution reached only 5.5 tons $/ \mathrm{km}^{2}$. (Environmental Year-Book...).

Also in the case of air pollution from $\mathrm{NO}_{x}$, the highest levels are found in the North Bohemian Region (41 ton $/ \mathrm{km}^{2}$ annually) and in Prague (79.3). These areas - together with the Ostrava region, which is located close to the Polish industrial region Katowice - are extremely deteriorated. These regions belong among economically most important Czechoslovak districts already since the early phase of industrialization.

What generates important problems in industrial and urban areas is widespread smog. Unfavourable landscape morphology sometimes greatly contributes to the presence of smog, too. In some parts of Northern Bohemia, for instance, and in the Prague Basin (intersected by the deep valley of Vltava River), the daily concentrations of $\mathrm{SO}_{2}$ exceeded during January 1982 and February 1987 many times the hygienic limits. In the north Bohemian town Chomutov sulphuric concentrations exceed maximal limits on average 120 days a year. 
The territory of Slovakia is affected by air pollution much less than the Czech Republic, since there are only few coal-fired plants. In 1989, Slovakia produced approximately $27 \%$ of all Czechoslovak electricity. Nevertheless, high concentrations of harmful substances were observed, too, particularly in deep and narrow valleys and in basins where a substantial part of population - and industry - are concentrated.

Emissions of solid materials, particularly fly ash and aerosols, increased from 800,000 tons in 1950 to 1.372 million in 1985. This amount then decreased to 991,000 tons (1989). Czechoslovakia produced about 7,000 tons of chlorinated fluorocarbons every year. With the generated amount of $\mathrm{CO}_{2}-60$ million tons per year - the Czechoslovakia's share on the total volume of global emissions was about $1.1 \%$, while the share on the world population was only $0.25 \%$.

The high degree of atmospheric pollution was considerably increased by emissions transferred from neighbouring countries, particularly from the former East Germany see figure No. 1. In Saxony, on the northern slopes of the Ore Mountains (Krušné hory), there is an extensive brown-coal region which has similar character as the North Bohemian Coal Basin. East German brown coal production was in 1980s two times higher (about 200 million tons), with significantly high air pollution - see table No. 3 . Similarly dirty industrial region in Polish part of Silesia is separated from the Czech territory only by a low mountain range. 52 \% of sulphuric emissions in Giant Mountains (Krkonoše) originated either in Poland or in Germany. However, Czechoslovakia was in the same time a significant exporter of industrial emissions; this "export" (transferred by wind and water) was about 20-60 \% higher than the "import". Only East Germany and Hungary "exported" more sulphur to Czechoslovakia than they received.

\subsection{Surface Water and Groundwater}

Water consumption in Czechoslovakia was extremely high in comparison with another countries. Average specific water consumption in the Czech Republic in the year 1970 was 227 litres/person/day, while in Bavaria only 207 litres. Until 1987 this figure increased up to 290 litres in the Czech Republic; in the same period in Bavaria there was a decrease to 200 litres. The total water consumption in the Czech Republic increased by $47 \%$ in between 1960-1985, in the case of groundwater it increased about five times during the last 40 years. With respect to the location of Czech Republic on main European watershed, these data are warning.

Serious water pollution on the Czech territory is primarilly caused by leaks from plants, agricultural cooperatives (mostly livestock farming), and from human settlements. The great output of waste water is only partially compensated by the construction of sewage plants; so far, even some bigger towns are not equipped with these facilities. Only ca $40 \%$ of waste water in Czechoslovakia was purified in a satisfactory way. In Prague - city with population of 1.25 million - out of more than 600 million litres of waste water which goes to the Vltava River every day, only $65 \%$ is thoroughly purified, and $11 \%$ of waste water is not cleaned at all (Levy 1992, p.14). Important sources of waste water exist also in agriculture: manure, artificial fertilisers, pesticides and soil particles from the land surface. These add approximately $50 \%$ to water contamination. Their impact has increased by about $25 \%$ within the last $10-15$ years.

Water quality deteriorated significantly during the last 50 years. In 1940, for instance, $87 \%$ of the total length of the main Czech river Elbe belonged to the water quality class I and II, while in 1980 the same water quality was found in only $3 \%$ of the river course. Hence, out of all examined Czech rivers $(7,000 \mathrm{~km})$, only $17 \%$ of the total length was in the best category (I), and $26 \%$ in the worst category (IV). There are considerable problems with the quality of drinking water, both from surface and ground sources. The 
average content of nitrates in groundwater has increased between 1960 and 1980 approximately four times in urban areas and more than two times in the countryside.

Giant water reservoirs have often negative impacts on local and regional scale and affect ecological systems. The cascade of three dams Nové Mlýny in south Moravia which caused much damage in valuable mead forests is a typical example. In Slovakia, the water reservoir Gabčikovo (with important hydroenergetic complex) threatens extensive area with pure groundwater.

\subsection{Forests}

The extent of forests in Czechoslovakia has increased since 1947 by $8 \%$, mainly due to afforestation. Both economic and political reasons played role (decrease of agriculture land and depopulation in previously German-settled areas). The most serious environmental problems are:

1) decrease of diversity of species;

2) acidification and poisoning of forests soils and forest damage.

Most of Czech forests are typical secondary forests which have been continuously planted since the 19th century. About $80 \%$ of forests in the Czech Republic are coniferous forests; in Slovakia only $42 \%$. The share of spruce (which was already in the 19th century considered the economically most important tree) rose from $27 \%$ (1950) to $50 \%$ in the period in 1980 s. Such forests are quite vulnerable to acid rain, storms and insecticides. The $\mathrm{pH}$ level should reach at least 4.2, but in some mountainous areas (e.g. Ore Mountains, Jizera Mountains, etc.) it is only 2.2. Forest soils in these areas must be supplied with $\mathrm{CaCO}_{3}$, which is mostly done from planes. In $1982,52.1 \%$ of Czechoslovak forests was significantly damaged (in the Czech Republic $55.7 \%$ and in Slovakia $49 \%$; Kopačka 1988, p. 338). According to a survey carried out by the UN Economic Commission for Europe in 1988 as much as $70.5 \%$ of Czechoslovak forests were damaged, and of these $5.4 \%$ were already dead (State of the Environment, p. 36). Out of European countries, the share of affected forests was higher only in Poland (79\%). Forest deterioration is at the lowest level in France (21\%), probably because of the high share of nuclear energy on the total energy output - see table No. 8. On the contrary, Poland has no nuclear power plants at all.

Forests are also seriously endangered by various insects, because trees became due to the pollution weaker and less resistant. In some regions forests are in disasterous conditions: Jizera Mountains are the most striking example. So called "mountain grassland" without any green trees is widely found there.

The state of forests has been worsened by massive-scale logging. In 1950 the output was 12.4 million $\mathrm{m}^{3}$ of timber and in 1985 it reached maximal level -19.7 million $\mathrm{m}^{3}$ (increase by $230 \%$ in the Czech Republic and by $73 \%$ in Slovakia - see table No. 2). This timber was partly exported abroad, even to countries with rich timber resources.

Eight Nationals parks existed in Czechoslovakia in 1991, with a total area of $3,108 \mathrm{~km}^{2}$. Ironically, the oldest National park in the Czech Republic - Giant Mountains (Krkonoše) - is now much damaged by atmospheric pollution and forests in altitudes over $800 \mathrm{~m}$ are practically destroyed.

\subsection{Other Environmental Changes (Selection)}

Due to limited space only selected environmental problems will be discussed in this chapter. Collectivization of agriculture brought the inevitable integration of holdings, reduced balks and extent of field roads. In 1948 there had been about 1.5 million of farms in Czechoslovakia, with average size 5-10 hectares. In 1986 there were only 
1,644 agricultural cooperatives with average size 2, 500 hectares and 253 state farms (located mainly in border regions with infertile soils) with average size 6,000 hectares (State of the Environment).

Introducing of large-scale agricultural machinery led to creation of very large fields which are in many regions neither ecologically, nor economically advantageous. The average size of land plots in Czechoslovakia was only 0.23 hectares in 1948. Until 1979 the same figure rose to approximately $10-15 \mathrm{ha}$, and in plains and fertile regions existed 100-200 hectares fields. Such giant units often did not correspond with geomorphological character of the Czech landscape and were ecologically unfavorable.

The abolishment of balks considerably decreased their positive function in the landscape, and also increased the threat of erosion. Economic losses through erosion were on the entire Czechoslovak area estimated at 2-3 billions Crowns per year (estimate from early 1980s). The annual soil removal reached 2 millions tons.

In 1989 the average fertiliser use per 1 hectare of agricultural land was in Czechoslovakia $235.5 \mathrm{~kg}$, in West Germany $257.7 \mathrm{~kg}$, in East Germany $292.0 \mathrm{~kg}$, in Poland $192.6 \mathrm{~kg}$, in Hungary $225.2 \mathrm{~kg}$, and in Austria $91.5 \mathrm{~kg}$. In Belgium this amount was $275.9 \mathrm{~kg}$, in the Netherlands $300.7 \mathrm{~kg}$, in France $193.5 \mathrm{~kg}$, in U.K.130.3 kg, and in the U.S.A. only $41.2 \mathrm{~kg}$ (Statistická ročenka, p. 683).

Open-cast mining significantly altered the physical appearance of landscape. The bottom of one of open mines near the town Most is below the sea level; an artificial cryptodepression was created. Most coal-fired plants were also located in northern Bohemia and the same was with heavy machinery and chemical plants. A "moon-like landscape" is found in many places.

Almost all residential areas face waste disposal problems. Technology of recycling or reusing of waste materials is not enough developed. Out of the total volume of solid industrial waste only about $38 \%$ is re-used, the rest being stored at dumps. The share of recycled materials is quite low, especially in the case of Czechoslovakia, which had very poor mineral resources.

\section{Main Causes of Environment Deterioration}

The degree of environmental deterioration in former Czechoslovakia, especially in the Czech republic, is really threatening.

Main reasons, which led to current environmental situation, may be indicated as follows:

1) Former political system;

2) Historical and geographical heritage;

3) Internal economical relations (modes of production).

\subsection{Political System}

Communist system could not survive due to two basic facts: it did not allow political plurality (similarly to nature, which needs biodiversity to survive) and was not economy viable.

Communist and capitalist systems differed not only in attitude towards ownership and in economic relations, but also in the way of GNP distribution and consumption. Political strategies aimed to maintaining of "social peace", to provide all people with certain income, the policy of zero unemploynment (everybody was legally forced to work), absolutely free of charge health care, welfare system which compensated for the lack of some civil rights and liberties - all this was a very expensive policy. The existence of non-efficient plants, factories, agricultural enterprises and cooperatives, which 
produced non-competitive goods, did not generate any structural changes in industry and the whole economy. This situation required more financial subsidies than it was economically viable. Huge financial sources were extracted from GNP and therefore could not be invested into much needed technological development. It was a shortsighted strategy. In short perspective, the system worked. In longer perspective, however, the final result was negative. In comparison with developed countries, however, the "wealth of nation" or GNP was relatively decreasing.

Capitalist system in developed countries underwent a very different development. Only economically profitable enterprises could survive under the capitalist system (at the cost of unemployment, and sometimes weaker welfare system). A larger amount of profit could have been invested into technological improvements, structural changes, etc. In the longer perspective this has resulted into the increase of GNP and "wealth of nation". Capitalist system produces more profit, part of which may be used also for ecological investments.

The recent state of environment in the Czech Republic does not correspond with the promises and proclamations made by the Communist régime. Let us now examine some other reasons which led to the current state.

\subsection{Historical and Economical Reasons}

Until 1948 Czechoslovakia consisted of two parts. Each of them had undergone a very different development. The western part, which became recently the independent

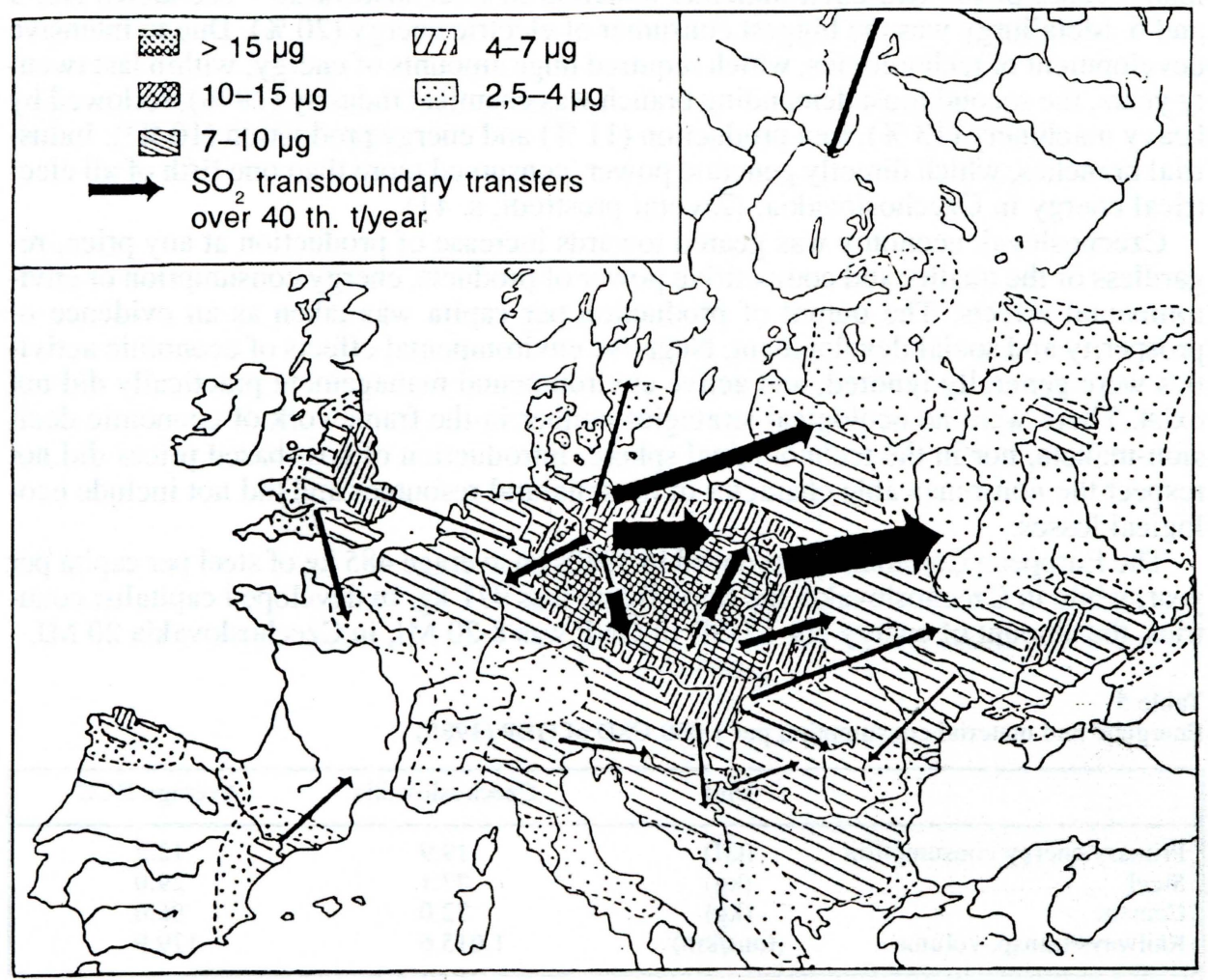

Fig. 1 - Air pollution in Europe 1988. Estimation of average annual concentration of SO in mg. $\mathrm{m}^{-3}$. (From Štulc, M., Götz, A., 1994: Krajina a životní prostředí pohledem geografie. Praha, ČEÚ.) 
Czech Republic, was relatively developed; the eastern part, Slovakia, was underdeveloped. Since 1945, Czechoslovak governments aimed to fully industrialize Slovakia and to reduce economic and social inequalities. This aim was fulfilled. Unfortunately, industrialization - which involved transformation of agricultural countries and regions into industrialized ones - took in Czechoslovakia a special form of so called "socialist industrialization." This was based on the nationalization of private ownership, which was largely transferred into socialist or "collective" enterprises. Concepts of central planning were introduced in all economic sectors; stress was put on the development of heavy industry.

This form of industrialization was connected with very intensive exploitation of all available human and natural sources and increased the self-sufficiency in the field of energy supply. Power supply was historically based on exploitation of rich domestic coal deposits. Most investments were allocated to heavy industry, which generated a rapid increase of resource demand, high specific consumption per unit of production and technological backwardness behind developed countries. This basic structure was much influenced by exploitation of energy sources, which was characterized by a high share of low quality brown coal, which was - and still is - burned in power plants. Productional consumption, i.e. the part of GNP re-invested into manufacturing of means of production, multiplied 7 times between 1950 and 1989 and its share on the social product (social product approximately equals GDP) output increased from $47 \%$ to $63 \%$ (see Table 2). Thus, almost two thirds of the total production was consumed by itself.

High consumption of electrical energy and the ways of its production belong among main causes of the bad environmental situation in Czechoslovakia - see tables No. 5 and 6. Metallurgy was the biggest consumer of electric energy (20\%). Due to intensive development of technologies, which required huge amounts of energy, within last twenty years, the second most demanding branch was chemical industry (18\%), followed by heavy machinery $(13 \%)$, fuel production $(11 \%)$ and energy production $(10 \%$ !). Industrial branches, which directly generate power, consumed more than one fifth of all electrical energy in Czechoslovakia. (Životní prostředí, s. 41).

Czechoslovak economy was geared towards increase of production at any price, regardless of the quality and competitive power of products, energy consumption or environmental effects. The output of production per capita was taken as an evidence of prosperity and social development. Negative environmental effects of economic activities were generally ignored, and active environmental management practically did not exist. There were no ecological strategies neither in the framework of economic decision-makers, nor in the technological sphere. Introduction of cost-based prices did not respect the non-renewable character of most natural resources and did not include ecological losses.

The European Community produced in 1980s on average $485 \mathrm{~kg}$ of steel per capita per year, while in Czechoslovakia the same figure was $971 \mathrm{~kg}$. In developed capitalist countries, the amount of energy per 1 USD of GNP was 8-20 MJ, in Czechoslovakia $20 \mathrm{MJ}$.

Table 5

Energetic and material consumption per 1,000 USD of GDP (1985)

\begin{tabular}{|lccc|}
\hline & Unit & Czechoslovakia & Average DCC \\
\hline Primary energy consumption & $(\mathrm{GJ})$ & 19.9 & 12.2 \\
Steel & $(\mathrm{kg})$ & 77.1 & 29.0 \\
Cement & $(\mathrm{kg})$ & 72.0 & 86.0 \\
Railways transp. volume & (tons/km) & $1,015.6$ & 179.9 \\
\hline
\end{tabular}

Source: Životní prostředí České republiky. Vývoj..., p. 117. DCC = developed comparable countries: Austria, Switzerland, Belgium, the Netherlands, Finland, Denmark, Norway, Sweden. 
Expensive way of economic development and high levels of energy production are clearly demonstrated by the following comparison:

Table 6

Output of coal and electrical energy per capita (1989)

\begin{tabular}{|lrc|}
\hline Country & Coal ${ }^{1}(\mathrm{~kg})$ & Electricity $(\mathrm{kWh})$ \\
\hline Czechoslovakia & 7,630 & 5,704 \\
West Germany & 3,025 & 7,112 \\
East Germany & 18,103 & 5,472 \\
Austria & 294 & 6,584 \\
Poland & 6,590 & 3,843 \\
Hungary & 1,893 & 2,797 \\
the Netherlands & - & 4,926 \\
Belgium & 190 & 6,796 \\
France & 204 & 7,277 \\
U.K. & 1,753 & 5,472 \\
U.S.A. & 3,556 & 11,888 \\
\hline
\end{tabular}

Source: Statistická ročenka...1991, p.661-3

$1=$ black and brown coal

Since the starting phase of the Industrial Revolution, coal extraction gradually adopted a decisive role and belonged among relatively progressive and stabilizing economical indicators until 1970s. In 1870, the output of brown coal was only 1.8 mil. tons, in 1900 17.6 mil. tons. About the same amount was extracted in 1937. As regards black coal, figures are as follows: 3.9 mil. tons in 1870, 9.7 mil. t. in 1900, and 16.7 mil. t. in 1937. Coal extraction has much increased after 1945. Since 1955, the output of brown coal rose from 40.8 million tons to 90.9 million tons (1989). $96 \%$ of this amount was extracted on the territory of the Czech Republic. The output of black coal increased in between 1955-1989 from 20.6 to 25.1 million tons and was confined only to the Czech territory. (Statistická ročenka).

Under the above mentioned economic conditions it was difficult to start reasonable environmental programmes or ecological investments aimed at technological and environmental improvements. Economic losses due to environmental deterioration were estimated to reach 5-7 \% of GNP during 1980s, i.e. approximately 28-39 billions of Czech Crowns per year. Some damages, however, can not be valued only in terms of money. The state budget in the period 1986-1990 allocated on average only 3.5 mld. Crowns per year to ecological investments. This sum covered just $9-12 \%$ of losses in the period 1985-1990. (Kopačka 1988, p. 331). Small increase of ecological investments in the second half of the 1980s was connected with the governmental Environmental Programme, which was approved in 1985. Still, such increase was insufficient.

Table 7

Structural development of primary energy sources in Czechoslovakia 1965-1989 (in \%)

\begin{tabular}{|lrrrr|}
\hline & 1965 & 1975 & 1980 & 1989 \\
\hline Coal & 82.9 & 66.4 & 65.7 & 57.1 \\
Natural gas & 1.5 & 5.5 & 6.0 & 13.0 \\
Crude oil & 11.7 & 24.3 & 25.1 & 20.2 \\
Other & 3.9 & 3.8 & 3.2 & 9.7 \\
\hline TOTAL & 100.0 & 100.0 & 100.0 & 100.0 \\
\hline
\end{tabular}

Source: Životní prostředí.., p. 120. 
The periodization of economic development in Czechoslovakia in between 19481989 with respect to development of the ecological situation and to environmental protection can be characterized as follows:

Period 1948-1960: rapid extensive economic development based on large investments and restructuring of economy; first environmental problems emerged, but only limited action to solve them was taken.

Period 1960-1970: economic crisis 1962-1964, in the second half of 1960s a modest economical revival, attempt to introduce economic reforms in 1968. First signs of serious environmental degradation, yet still mostly of local extent. Large-scale water pollution. First, yet inconsistent attempts to solve environmental problems. First voluntary environmental organizations established.

Period 1971-1989: economic slow-down and exploitation of all available natural resources (mainly in 1970s). Extensive degradation of the environment. Efforts to maintain the achieved standard of living at the expense of environmental deterioration. In the second half of 1980s first legal attempts to solve environmental problems. Signs of modest improvements in selected fields (mainly due to decrease of coal extraction). Attempts to intensify economy, but technological improvements remained scarce (Compare similarly Životní prostředí, 9-10).

\section{Conclusion: Possible Solutions}

The share of environmentally oriented investments in Czech economy still remains low. There has been some recent increase: $1.47 \%$ per year in the period 1971-1975 and about $2.0 \%$ in between 1986-1990. In developed countries, however, the same figure varies within the range 5-10\%. It is very important to improve what has been spoilt; equally important is to increase the economic efficiency. Not only coal, but also other energetic sources such as natural gas and crude oil belong among non-renewable elements and their deposits are limited. The costly transformation of Czech energetic basis (reduction of coal-fired plants and increase of natural gas and crude oil) is not.a longterm solution. A possible alternative might be the search for new sources of energy. A very small step has already been done by introducing of nuclear plants. Deposits of uranium ore, however, are limited, too. Can man rely on energy from thermonuclear fusion in future? And what about solar energy, which seems to be so promising and which has no limits? Technological improvements and economic restructuring should decrease energy demand, too. This could be an elegant solution - yet very expensive. The environmentally most sensitive energy is that energy, which has not been generated. Czech Republic and Slovakia have following possibilities how to improve their environmental situation:

1. to modernize technological processes in all branches of economy and to launch economic restructuring aimed at reduction of energy consumption; 2 . to decrease the output of brown coal and power generation in coal-fired plants; 3 . to replace coal-fired plants with nuclear power plants (Temelín); in Slovakia it is essential to put into operation the Gabčikovo hydroenergetic plant and the nuclear power plant Mochovce. 4. to support railway transport instead of road transport, including the complete electrification of railway tracks.

The strongest objections against the Temelín nuclear plant come from Austria, which produces about two thirds of electrical energy in hydroenergetic plants, while Czech Republic much relies on thermal (mostly coal-fired) plants - see table No. 8. Which country is more polluted? On the other hand, the negative Hungarian attitude towards the Gabčikovo-Nagymaros hydroenergetic system does not correspond with the high share of "dirty energy" generated in Hungary. 
Table 8

The share of thermal, hydroenergetic, and nuclear power plants (measured by total capacity of turbines, in \%) - 1989

\begin{tabular}{|lccc|}
\hline Country & Thermal & $\begin{array}{c}\text { Plants } \\
\text { Hydroenergetic }\end{array}$ & Nuclear \\
\hline Czechoslovakia & 68.6 & 14.2 & 16.2 \\
West Germany & 68.0 & 6.8 & 22.5 \\
East Germany & 78.2 & 7.3 & 7.3 \\
Poland & 89.7 & 6.2 & - \\
Hungary & 74.9 & 0.7 & 24.3 \\
Austria & 31.3 & 56.9 & - \\
Belgium & 46.6 & 9.1 & 35.7 \\
the Netherlands & 96.7 & 0.1 & 2.9 \\
France & 21.7 & 23.8 & 50.3 \\
U.K. & 83.0 & 6.0 & 11.0 \\
U.S.A. & 71.9 & 13.2 & 14.3 \\
\hline
\end{tabular}

Source: Statistická ročenka....1991, p. 662

11988

This article outlined some basic features. Much more remains to be done: changes in the legal system, more pronounced international cooperation, and ecological education in order to change the general system of values.

\section{References:}

Atlas životního prostředí a zdraví ČSFR (Atlas of the Environment and Health of Population of the CSFR). Institute of Geography of the CSAS, Federal Committee for the Environment, Brno-Praha 1992.

Environmental Year-Book of Czech Republic 1991. Ministry for Environment of the Czech Republic and CEI 1992, Prague, $292 \mathrm{pp}$.

Historical Geography of Environmental Changes. Edited by V.Annenkov and L. Jeleček. Historická geografie - Historical Geography, Vol. 27. Published on the occasion of the 24th International Geographical Congress in Sydney 1988. Institute of Czechoslovak and World History of the CSAS, Prague $1988,400 \mathrm{p}$.

JELECEK, L. (1988): Some Thoughts on Historical Geography of Environmental Changes. Development of Agricultural Landscape of Czech Lands in Historical Perspective. In: Historická geografieHistorical Geography, Vol. 27, Prague, pp. 351-350.

JELEČEK, L. (1993): Environmenal Changes in the Communist Era of Czechoslovakia. University of Kansas, Rockefeller Program in Nature, Culture, and Technology, Lawrence, 22 p., 5 fig., (Mimeographed).

KOPACKA, L. (1988): Economy and Environmental Changes of the Czechoslovak Socialist Republic and Global Ecology Problem. In: Historická geografie - Historical Geography, Vol.27, Prague, pp. 307-350.

LEVY, P. (1992): Czechs and Balances. In: Earthwatch July/August.

National Report of the Czech and Slovak Federal Republik. United Nations Conference on Environment and Development, Brazil, June 1992. Czechoslovak Academy of Sciences and the Federal Committee for the Environment, Prague, March 1992, 142 p.

State of the World 1991. Worldwatch Institute, Washington 1992.

State of the Environment in Czechoslovakia. Federal Committee for the Environment, Vesmír, Prague $1992,120 \mathrm{p}$.

Statistická ročenka Ceské a Slovenské Federativní Republiky 1991 (Statistical Yearbook of the Czech and Slovak Federal Republic), SEVT, Praha 1991.

ŠTÉPÁNEK, V. (1992): The Iron Curtain and Its Impact on the Environment in the Czech Republic. AUC - Geographia 1, p. 59-63.

Životní prostředí Ceské republiky. Vývoj a stav do konce roku 1989. (Environment of the Czech Re- 
public. Development and State Until the End 1989). Ministerstvo životního prostředí ČR, Academia, Praha $1990,281 \mathrm{p}$.

\section{Shrnutí}

\section{HOSPODÁŘSKO-POLITICKÝ VÝVOJ A ZMĚNY ŽIVOTNIIHO PROSTŘEDÍ ČESKOSLOVENSKA V LETECH 1948 - 1989}

Článek nastiňuje na pozadí některých hlubších historicko-geografických kořenů vývoje Československa v období 1948 - 1989 (část 2) charakter současného stavu jeho životního prostředí, a to především v České republice (3). Charakterizuje hlavní trendy negativních změn životního prostř̌edí (znečištění vzduchu, vodních zdrojủ, stav lesủ atd.) v jejich srovnáni se středoevropskými a některými dalšími vyspělými státy. $\mathrm{V}$ dalším výkladu se autor snaží nalézt některé politické, sociální a především ekonomické př́činy tohoto vývoje (4). Mezi ně zařazuje jak systémové vady režimu, vládnoucího ve sledovaném období, které spočívaly v neexistenci diversity jeho politického systému, tak nevýkonné hospodářství, jehož rozvoj byl založen na extenzivním čerpání přírodních a společenských zdrojủ. Př́ičiny nepřiznivého stavu našeho životního prostředí nalézá také v širších ekonomických a politických souvislostech tzv. socialistické industrializace a její energetické náročnosti, i v neschopnosti a nemožnosti nastoupit cestu strukturálních přeměn ekonomiky a její "ekologizace". I v této části se vychází také $\mathrm{z}$ mezinárodního srovnání. V závěru 4. části je návrh periodizace "hospodářsko-ekologického" vývoje Československa a ochrany jeho životního prostředí. V poslední části jsou naznačena některá možná východiska $\mathrm{z}$ naši současné ekologické situace.

Obr. 1 - Průměrné roční koncentrace imisí $\mathrm{SO}_{2}$ a jejich dálkové přenosy v Evropě (stav v r. 1988). 